\title{
PENGEMBANGAN MEDIA PEMBELAJARAN INTERAKTIF PADA PEMBELAJARAN BAHASA INDONESIA KELAS III SEKOLAH DASAR
}

\section{DEVELOPMENT OF INTERACTIVE LEARNING MEDIA IN INDONESIAN LEARNING CLASS III ELEMENTARY SCHOOL}

\author{
Nur Afifah ${ }^{1}$, Otang Kurniaman ${ }^{2}$, Eddy Noviana ${ }^{3}$ \\ 1,2,3 Program Studi Pendidikan Guru Sekolah Dasar, FKIP Universitas Riau \\ Pekanbaru, Indonesia
}

Email:nur.afifah0554@student.unri.ac.id ${ }^{1}$,otang.kurniaman@lecturer.unri.ac.id ${ }^{2}$, eddy.noviana@lecturer.unri.ac.id ${ }^{3}$

\begin{tabular}{l} 
Submitted \\
26 Desember 2021 \\
Accepted \\
09 Januari 2022 \\
Revised \\
22 Januari 2022 \\
Published \\
31 Januari 2022 \\
\hline
\end{tabular}

Kata Kunci:

Media pembelajaran interakitf; Genially;

Pembelajaran Bahasa Indonesia;

Keyword: interactive learning media; Genially; Indonesian language learning;

\section{Abstrak}

Penelitian ini menggunakan metode penelitian Reseacrh and Development $(R \& D)$ dengan model ADDIE (Analysis, Design, Development, Implementation, and Evaluation). Penelitian ini menggunakan angket sebagai instrument pengumpulan data uji validasi dari ahli media, ahli materi, ahli bahasa, praktisi, dan tanggapan siswa kelas III Sekolah Dasar. Pengumpulan data pada penelitian ini dilakukan di SD Al-Furqon Islamic School Pekanbaru. Hasil validasi media pembelajaran interaktif mendapatkan persentase kelayakan sebesar $94 \%$ dengan kategori "Sangat Layak", dari hasil validasi ahli materi mendapatkan persentase 100\% dengan kategori "Sangat Layak", dari hasil validasi ahli bahasa mendapatkan persentase 92\% dengan kategori "Sangat Layak", dari hasil validasi praktisi I mendapatkan persentase 95\% dengan kategori "Sangat Layak", dari hasil validasi praktisi II mendapatkan persentase 96\% dengan kategori "Sangat Layak", dari hasil uji coba satu-satu dengan 3 orang siswa mendapatkan persentase 83,33\% dengan kategori "Sangat Layak", dan dari hasil uji coba terbatas dengan 8 orang siswa mendapatkan persentase 89,7\% dengan kategori "Sangat Layak". Berdasarkan dari hasil tersebut dapat disimpulkan bahwa media pembelajaran interaktif yang dikembangkan sangat layak digunakan untuk proses pembelajaran Bahasa Indonesia pada materi Dongeng kelas III Sekolah Dasar di SD Al-Furqon Islamic School Pekanbaru.

\section{Abstract}

This study uses Research and Development $(R \& D)$ research methods with the ADDIE (Analysis, Design, Development, Implementation, and Evaluation) model. This study uses a questionnaire as an instrument for collecting validation test data from media experts, material experts, linguists, practitioners, and responses from third grade elementary school students. Data collection in this study was conducted at Al-Furqon Islamic School Pekanbaru. The results of the validation of interactive learning media get a feasibility percentage of $94 \%$ in the "Very Eligible" category, from the results of the validation of material experts get a percentage of $100 \%$ in the "Very Eligible" category, from the validation results linguists get a percentage of $92 \%$ with the "Very Eligible" category, from the results of the validation practitioners I get a percentage of $95 \%$ with the category "Very Eligible", from the results of the validation practitioners II get a percentage of $96 \%$ with the category "Very Eligible", from the results of a one-on-one trial with 3 students getting a percentage of $83.33 \%$ with "Very Eligible" category, and from the results of a limited trial with 8 students getting a percentage of $89.7 \%$ in 
the "Very Eligible" category. Based on these results, it can be concluded that the interactive learning media developed is very feasible to use for the Indonesian language learning process in the fairy tale material for class III Elementary School at Al-Furqon Islamic School Pekanbaru.

Citation :

Afifah, N., O, Kurniaman,. E, Noviana. (2022) Pengembangan Media Pembelajaran Interaktif pada Pembelajaran Bahasa Indonesia Kelas III Sekolah Dasar. Jurnal Kiprah Pendidikan, 1 (1), 33-42.

\section{PENDAHULUAN}

Perkembangan ilmu pengetahuan sangat mempengaruhi pada kehidupan sehari-hari, yaitu salah satunya pendidikan. Karena setiap individu dituntut untuk harus memiliki pendidikan yang mencakup intelektual yang tinggi serta memiliki keterampilan. Semakin lama pendidikan akan mengalami perubahan yang sangat pesat, karena sudah banyak kita temui pembaharuanpembaharuan dibidang teknologi yang sangat berperan penting untuk menunjang dan meningkatkan kualitas pembelajaran. Sehingga guru melakukan pembaharuan dalam proses pembelajaran dengan melakukan pengembangan media pembelajaran. Hal ini perlu dilakukan agar proses pembelajaran menarik, tidak monoton dan tidak membosankan sehingga tida menghambat terjadinya proses pembelajaran. Oleh karena itu peran media terhadap proses pembelajaran sangat penting karena akan menjadikan proses pembelajaran menjadi lebih menarik, bervariasi, dan tida membosankan (Muhson, 2010:1).

Berdasarkan hakikat proses pembelajaran tersebut, media pembelajaran merupakan sarana untuk menyampaikan dan mendapatkan pesan, sedangkan penerima pesannya adalah peserta didik bahkan pendidik itu sendiri. Sebuah pesan disapaikan oleh pendidik atau sumber-sumber lain ke dalam simbol-simbol komunikasi, baik secara verbal (lisan ataupun tertulis) maupun secara non verbal atau visual (Setyawan, 2012:2).

Media yang sering digunakan dalam pembelajaran masih belum bisa meningkatkan keefektivitasan pencapaian hasil belajar karena kriteria dalam pemilihan media pembelajaran yang belum sesuai. Dalam memilih media untuk pembelajaran menurut Sudjana dan Rivai (2002:34) sebaiknya memperhatikan kriteria-kriteria berikut: a) Ketepatannya dengan tujuan pembelajaran, b) Dukungan terhadap isi bahan ajar, c) Kemudahan memperoleh media.

Saat ini masih sangat sedikit upaya untuk mengembangkan konten pembelajaran. Kebanyakan konten pembelajaran yang digunakan masih dijelaskan secara lisan. Hal ini memunculkan adanya kebutuhan untuk mengembangkan konten pembelajaran berbasis multimedia berupa media pembelajaran interaktif yang memanfaatkan unsur audio dan visual. Audio-Visual merupakan pembelajaran berbasis teknologi yang dapat digunakan sebagai sarana alternatif dalam mengoptimalkan proses pembelajaran, karena dengan menggunakan audio-visual media mudah dikemas dala proses pembelajaran, media lebih menarik untuk pembelajaran, dan dapat diperbaiki setiap saat. Melalui audio-visual pembelajaran dapat lebih interaktif dalam proses pembelajaran. Hal ini diharapkan dapat mewujudkan proses pembelajaran menjadi lebih efektif dan meningkatkan kualitas proses belajar mengajar terutama pada pembelajaran Bahasa Indonesia materi Dongeng kelas III Sekolah Dasar.

Ada banyak media yang bisa membantu dalam proses pembelajaran, salah satunya dengan menggunakan perangkat lunak atau software komputer. Priyanto Hidayatullah dalam Priandana \& Asto (2015: 2) mengatakan kebanyakan software presentasi sekarang hanya sanggup menampilkan materi pelajaran secara statis. Salah satu yang bisa menjadi alternatif adalah educational animation, yang kalau diambil pengertian sempitnya adalah visualisasi materi pelajaran dalam bentuk animasi 
untuk digunakan dalam kegiatan belajar mengajar. Media pembelajaran interaktif diatas dapat dibuat menggunakan software komputer yaitu website Genially.

Website Genially digunakan sebagai pertimbangan untuk membuat media pembelajaran interaktif karena memiliki kelebihan salah satunya adalah memiliki fitur-fitur yang disediakan sangat menarik. Sehingga proses belajar mengajar tidak monoton dan tidak membosankan dengan materi yang hanya menggunakan tulisan dan gambar.

Pembelajaran Bahasa Indonesia dengan materi Dongeng bertujuan untuk menguasai standar kompetensi yang telah ditetapkan, sehingga dibutuhkan pemahaman yang cukup untuk melaksanakan pembelajaran terutama teori. Untuk meminimalisir ketidakpahaman dalam pembelajaran teori tersebut, perlu digunakan media pembelajaran yang sesuai. Media pembelajaran yang digunakan dalam proses pembelajaran selama ini masih menggunakan metode ceramah. Dengan hanya menggunakan metode ceramah siswa menjadi lebih bosan dan siswa tidak dapat belajar secara mandiri.

Media pembelajaran interaktif dapat membantu proses pembelajaran sehingga makna pesan yang disampaikan menjadi lebih jelas dan tujuan pendidikan dapat tercapai dengan efektif dan efisien. Media adalah sebuah sarana yang digunakan untuk menyampaaikan sebuah informasi kepada penerima pesan, sehingga penerima dapat memahami pesan tersebut dengan baik.

Media yang sering digunakan dalam pembelajaran adalah media audio-visual, karena media audio-visual dapat dilihat, dapat diraba, dapat dirasakan, dan dapat didengar. Media interaktif dapat digunakan sebagai media pembelajaran karena dapat menarik perhatian peserta didik, karena Genially memiliki gambar dan cerita yang menarik, sehingga dapat menarik perhatian peserta didik dan peserta didik tidak bosan dalam pembelajaran. Media interaktif ini dapat diakses online melalui web site www.genial.ly. yang bermuatan materi Dongeng tema II subtema I untuk anak kelas III Sekolah Dasar.

Pembelajaran Bahasa Indonesia merupakan salah satu mata pelajaran yang dapat melibatkan peserta didik secara langsung dalam memperoleh pengetahuannya sehingga memunculkan rasa ingin tahu dalam diri siswa. Pada pembelajaran Bahasa Indonesia materi yang akan dibahas yaitu mengenai dongeng pada sekolah dasar dengan menggunakan telepon seluler masih jarang kita temui. Biasanya pembaca memperoleh informasii mengenai dongeng pada sekolah dasar hanya melalui buku, CD, atau media cetak lainnya. Hal ini memunculkan ide untuk membuat media interaktif bagi pembaca dongeng pada sekolah dasar.

Media interaktif yang digunakan adalah Genially yang dapat diakses online melalui website $w w w$.genial.ly. yang dapat digunakan untuk membantu para pembaca menikmati dan memahami dongeng yang ada tanpa harus rumit membaca satu per satu kata isi dongeng tersebut. Umumnya pembelajaran Bahasa Indonesia pada materi Dongeng yang disajikan dalam pemb Bahan ajar dalam aplikasi android berupa teks dongeng. Dongeng merupakan cerita prosa rakyat yang tidak dianggap benar-benar terjadi dan disebarkan secara lisan (Saidah dan Damariswara, 2019: 74). Sedangkan menurut Gusal (2015:1) dongeng adalah sebuah cerita yang direka oleh pencerita dengan maksud tertentu.elajaran memiliki pengaruh yang baik bagi siswa. Akan tetapi menggunakan android menjadi lebih praktis.

Literasi yang terdapat dalam aplikasi android yakni terdapat 8 teks dongeng dengan isi dan pesan yang berbeda. Literasi secara harfiah adalah kemampuan membaca dan menulis. Tahap literasi menurut Khotimah, dkk (2020:147) yakni pembiasaan, pengembangan, dan pembelajaran. Aplikasi android memuat ketiganya, pembiasaan membaca teks dongeng, pengembangan aplikasi android materi dongeng, serta menerapkan dalam pembelajaran dongeng. Aplikasi android materi dongeng kelas 3 perlu diaplikasikan dalam dunia pendidikan. 
Oleh karena itu, penelitian ini bertujuan untuk mengetahui kepraktisan aplikasi android materi dongeng berbasis kearifan lokal dan permainan bahasa. Hasil pada penelitian kepraktisan aplikasi android materi dongeng kelas III SD berbasis kearifan lokal dan permainan bahasa memperoleh skor 93,8\%. Skor tersebut dikategorikan dalam sangat praktis dan dapat digunakan tanpa revisi.

\section{METODE PENELITIAN}

Penelitian dilakukan pada Sekolah Dasar di Pekanbaru. Penelitian ini akan dilaksanakan pada semester ganjil tahun ajaran 2021/2022. Penelitian dilakukan menggunakan metode penelitian dan pengembangan atau dalam bahasa Inggris disebut Research and Development (R\&D) yaitu metode penelitian yang digunakan untuk menghasilkan produk tertentu dan menguji keefektifitasan produk tersebut. Dengan menggunakan konsep ADDIE dikembangkan untuk membangun pembelajaran yang berbasis kinerja yang diaplikasikan dalam filosofi pendidikan yang berpusat pada siswa, inovatif, otentik dan menginspirasi. Prosedur pengembangan menggunakan model ADDIE (Analysis, Design, Development, Implementation, dan Evaluation) karena model ADDIE sangat sering digunakan untuk dapat menghasilkan sebuah desain:

\section{a. Analyze (Analisis)}

Tahapan analisis merupakan tahapan awal yang dilakukan dalam penelitian pengembangan. Tujuan dari analisis tersebut merupakan untuk menetapkan materi dan untuk mendapatkan gambaran mengenai media pembelajaran yang dibutuhkan oleh siswa. Analisis yang dilakukan dalam penelitian pengembangan ini yaitu:

1) Analisis Peserta Didik

Analisis peserta didik dilakukan pada awal perencanaan dengan cara mengamati karakteristik peserta didik agar media yang dikembangkan sesuai dengan minat siswa. Menurut Piaget dalam (Fatimah Ibda, 34:2015) pada usia 6-12 tahun anak berada dalam perkembangan tahap operasional konkrit. Anak lebih cenderung menyukai pembelajaran yang menyenangkan dan tidak terlalu kaku atau monoton, oleh karena itu dengan adanya pengembangan media interaktif diharapkan siswa lebih menyenangi pembelajaran dan dapat menggali informasi yang ada didalam media interaktif tersebut.

2) Analisis Kurikulum

Kurikulum merupakan suatu program pendidikan yang berisikan berbagai bahan ajar dan pengalaman belajar yang diprogramkan, direncanakan dan dirancang secara sistematik atas dasar norma-norma yang berlaku yang dijadikan pedoman dalam proses pembelajaran bagi tenaga kependidikan dan peserta didik untuk mencapai tujuan pendidikan (Dakir, 2004: 3). Sedangkan pengertian kurikulum menurut Undang-Undang Nomor 20 tahun 2003 pasal 1 Ayat 19 adalah seperangkat rencana dan pengaturan mengenai tujuan, isi dan bahan pelajaran serta cara yang digunakan sebagai penyelenggara kegiatan pembelajaran untuk mencapai tujuan pendidikan tertentu. Pada pelaksanaan pembelajaran dengan menggunakan kurikulum 2013 yang dilakukan secara menyeluruh dalam satu tema. Dan peneliti ingin mengembangkan media interaktif berbasis Genially pada materi Dongeng kelas III di Sekolah Dasar.

\section{b. Design (Desain)}

Tahapan desain ini dilakukan dengan melakukan perancangan media interaktif Genially, dengan menetapkan alur Genially yang dibuat serta pembuatan skrip atau naskah. Serta pembuatan gambar dan tulisan juga dilakukan dalam tahapan desain agar mempermudah dalam tahapan pengembangan. c. Development (Pengembangan)

Setelah tahap desain selesai, sehingga dapat menghasilkan produk yang ingin diteliti oleh peneliti. Tahapan selanjutnya yang dilakukan ialah tahapan pengembangan. Langkah awal yang 


\section{Kiprah Pendidikan}

dilakukan didalam tahapan pengembangan yaitu validasi produk dan revisi produk. Validasi dilakukan oleh 3 para ahli, yaitu ahli media, ahli materi dan ahli bahasa. Validasi dilakukan dengan mengisi instrumen yang sudah disediakan oleh peneliti. Hasil dari validasi yang berupa saran dan masukkan sangat berguna untuk penyempurnaan media yang diteliti.

d. Implementation (Implementasi)

Pada tahapan ini, peneliti melakukan implementasi terhadap media interaktif berbasis Genially tersebut pada proses pembelajaran pada siswa sekolah dasar. Langkah pertama dengan melakukan uji one by one. Setelah uji one by one dilakukan kemudian peneliti melakukan uji coba terbatas untuk mengetahui respon peserta didik terhadap Genially tersebut.

\section{e. Evaluation (Evaluasi)}

Berdasarkan tahapan implementasi ini, media interaktif berbasis Genially perlu dievaluasi. Pada tahapan evaluasi dilakukan revisi akhir terhadap produk yang dikembangkan berdasarkan saran dan masukan yang diperoleh dari peserta didik selama tahapan implementasi dilakukan.

Sementara itu, subyek uji coba dalam penelitian ini adalah media interaktif berbasis Genially pada pembelajaran Bahasa Indonesia materi Dongeng kelas III di sekolah dasar. Subyek uji coba produk dilakukan dengan menggunakan uji lapangan terbatas.

Instrumen yang digunakan dalam penelitian ini adalah lembar instrumen ahli media, ahli materi dan instrumen ahli media. Instrumen tersebut digunakan sebagai dokumentasi kelayakan media pembelajaran yang dikembangkan dalam penelitian ini. Instrumen berisi pertanyaan- pertanyaan yang berkaitan dengan media pembelajaran sebagai dasar kelayakan ahli media, ahli bahasa, ahli materi dan anak didik.

\section{1) Angket uji validasi}

Angket uji validasi merupakan suatu gambaran umum dari validator terhadap media pembelajaran. Fungsi dari lembar validasi ini adalah untuk mengetahui kelayakan media serta kriteria dengan kesesuaian media yang telah di rancang oleh peneliti.

2) Angket uji coba produk

Angket uji coba produk yang digunakan peneliti dalam penelitian ini merupakan responden yaitu siswa. Angket ini digunakan setelah melakukan uji coba pada media. Tujuan dari pengisian angket ini untuk mengetahui respon siswa terhadap media interaktif Genially pada materi Dongeng yang dapat dijadikan landasan untuk melakukan revisi produk yang telah dikembangkan.

Aspek peneliti yang dinilai oleh ahli dibuat dalam skala Likert dengan skor 1-4. Dengan menggunakan skala ini dapat memberikan kebebasan kepada validator dalam melakukan penilaian terhadap media yang dirancang. Validasi media ditentukan oleh rata-rata skor yang didapatkan oleh validator.

Tabel 1. Skor Penilaian

\begin{tabular}{cl}
\hline Skor Penilaian & \multicolumn{1}{c}{ Kategori } \\
\hline 4 & SS : Sangat Setuju \\
3 & S : Setuju \\
2 & KS : Kurang Setuju \\
1 & TS : Tidak Setuju \\
\hline
\end{tabular}

(Suryono, 2011)

Kriteria dalam mengambil keputusan dalam validasi media dapat dilihat di tabel. Media dapat digunakan jika penilaian rata-rata validator dikategorikan valid dan sangat valid. 
Tabel 2. Interval Rata-Rata Skor Penilaian

\begin{tabular}{cc}
\hline Rata-rata Skor & Kategori Validitas \\
\hline $81-100$ & Sangat Valid \\
$61-80$ & Valid \\
$41-60$ & Cukup Valid \\
$21-40$ & Tidak Valid \\
$0-20$ & Sangat Tidak Valid \\
\hline
\end{tabular}

(Suryono, 2011)

Sementara itu, kategori dalam kelayakan media yang dikembangkan di kategorikan sebagai berikut:

Tabel 3. Kriteria Kelayakan Media

\begin{tabular}{cc}
\hline Persentase Skor & Kategori Kelayakan \\
\hline$<21 \%$ & Sangat Tidak Layak \\
$21 \%-40 \%$ & Tidak Layak \\
$41 \%-60 \%$ & Cukup Layak \\
$61 \%-80 \%$ & Layak \\
$81 \%-100 \%$ & Sangat Layak \\
\hline
\end{tabular}

Arikunto dalam (Lis Ernawati, 207: 2017)

Media pembelajaran interaktif yang dikembangkan dapat digunakan jika penilaian rata-rata validator dikategorikan layak dan sangat layak. Analisis data uji coba produk menggunakan skala likert 1-4. Angket uji coba produk diberikan kepada siswa dengan maksud untuk menilai media yang digunakan dan guru juga diberikan angket sebagai respon guru terhadap media tersebut. Dengan diketahuinya presentase skor yang diperoleh, langkah selanjutnya merupakan tahap dalam menentukan kelayakan media.

\section{HASIL DAN PEMBAHASAN}

Dari hasil penelitian yang dilakukan menunjukkan penilaian terhadap media interaktif berbasis Genilly terdiri dari 5 aspek. Penilaian media interaktif berupa Genially terdiri dari 5 aspek. Pada aspek pertama yaitu aspek materi menunjukkan rata-rata skor 95\% dengan kategori sangat valid. Aspek penilaian kedua yaitu aspek desain Genially, pada aspek ini didapatkan rata-rata skor $96 \%$ dengan kategori sangat valid. Aspek ketiga yaitu aspek kesederhanaan, pada aspek ini didapatkan rata-rata 
skor 95\% dengan kategori sangat valid. Aspek keempat yaitu keterpaduan, pada aspek ini didapatkan rata-rata skor 92,5\% dengan kategori sangat valid. Aspek kelima yaitu keseimbangan, pada aspek ini didapatkan rata-rata skor $100 \%$ dengan kategori sangat valid. Dari kelima aspek tersebut, diperoleh rata- rata skor akhir dari penilaian validasi dan praktisi dengan menunjukkan skor 95,7\% dengan kategori sangat valid.

Tabel 4. Rata-rata Skor Validasi Media tiap Aspek dalam Media Interaktif

\begin{tabular}{ccc}
\hline Aspek Penilaian & $\begin{array}{c}\text { Persentase rata-rata } \\
\text { tiap aspek }\end{array}$ & Kategori Validasi \\
\hline Materi & $95 \%$ & Sangat Valid \\
Desain Komik & $96 \%$ & Sangat Valid \\
Kesederhanaan & $95 \%$ & Sangat Valid \\
Keterpaduan & $92,5 \%$ & Sangat Valid \\
Keseimbangan & $100 \%$ & Sangat Valid \\
\hline Rata-rata Skor & $\mathbf{9 5 , 7 \%}$ & Sangat Valid \\
\hline
\end{tabular}

Hasil dari tabel 4 menunjukkan bahwa media interaktif berbasis Genially yang dikembangkan dengan judul "Genially Dongeng" mendapatkan rata-rata skor dari tiap penilaian aspek senilai 95,7\% dengan kategori sangat valid. Penilaian yang dilakukan oleh validator dan praktisi mendapatkan kategori sangat valid dengan skor : validasi yang dilakukan oleh ahli media mendapatkan skor 94\%, validasi yang dilakukan oleh ahli materi mendapatkan skor $100 \%$, validasi yang dilakukan oleh ahli bahasa mendapatkan skor 92\%, validasi yang dilakukan oleh praktisi I mendapatkan skor 95\%, dan validasi yang dilakukan oleh praktisi II mendapatkan skor $96 \%$. Jadi skor rata-rata yang diperoleh dari validasi dan praktisi mendapatkan skor $95,4 \%$

Peneliti melakukan uji coba satu-satu dan uji coba terbatas. Pada uji coba satu-satu dilakukan dengan 3 orang siswa yang memiliki kemampuan yang berbeda. Hasil dari uji coba satu-satu didapat skor dengan rata-rata 83,33\% dengan menunjukkan kategori sangat layak. Tahapan selanjutnya yang dilakukan oleh peneliti yaitu uji coba terbatas yang dilakukan pada 8 orang siswa yang terdapat di SD Al-Furqon Islamic School Pekanbaru, skor rata-rata yang didapatkan 89,7\% dengan kategori sangat layak.

Tabel 5. Hasil Penilaian Uji Coba

\begin{tabular}{clcl}
\hline No & Tahapan Uji Coba & Persentase & Kategori \\
\hline 1 & Uji Coba Satu satu & $83,33 \%$ & Sangat Layak \\
2 & Uji Coba Terbatas & $89,7 \%$ & \\
\hline
\end{tabular}

Dari tabel 5, dapat dilihat bahwa uji coba terbatas memiliki persentase yang lebih tinggi dibandingkan dengan uji coba satu satu dengan persentase $89,7 \%$. Penggunaan media pembelajaran interaktif Genially dapat dilakukan siswa dalam pembelajaran secara mandiri, karena media pembelajaran interaktif Genially ini selain dilengkapi dengan cerita, media interaktif Genially juga disertai dengan materi pembelajaran dan kuis. 


\section{Hasil Pengembangan Media}

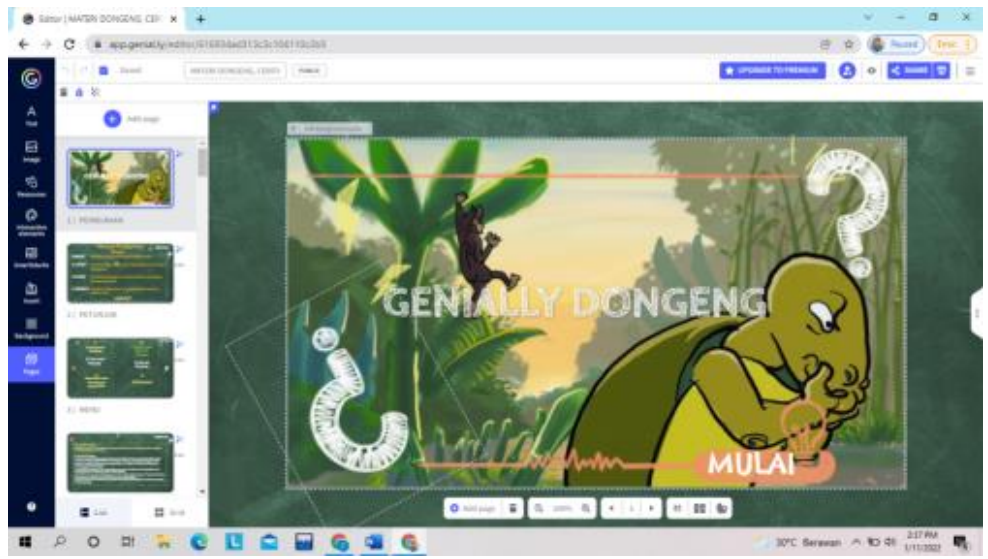

Gambar 1. Media Pembelajaran yang di kembangkan

Pada tahap pertama yaitu tahapan analisis, pengembangan media interaktif dilakukan dengan beberapa tahap yaitu analisis peserta didik. Analisis peserta didik dilakukan bertujuan untuk mengetahui karakteristik peserta didik agar media interaktif yang dikembangkan sesuai dengan kemampuan berfikir siswa kelas III sekolah dasar. Analisis kedua yaitu analisis kurikulum. Analisis kurikulum dilakukan oleh peneliti untuk menyiapkan kebutuhan-kebutuhan yang diperlukan dalam pengembangan media interaktif. Analisis yang ketiga yaitu analisis materi. Analisis materi dilakukan agar dalam proses pengembangan media interaktif peneliti dapat menyesuaikan materi yang akan dikembangkan dengan kompetensi dasar, indikator dan tujuan pembelajaran di dalam media interaktif.

Tahapan kedua dari pengembangan media interaktif adalah tahapan desain. Pada tahapan ini langkah awal yang dilakukan yaitu merancang media interaktif mulai dari pembuatan alur cerita, pembuatan script, mulai memperkenalkan fitur, kemudian menggunakan fitur yang telah disediakan, serta tutorial, dan penutup.

Tahap ketiga yaitu tahapan pengembangan. Tahapan ini dilakukan peneliti melakukan validasi atau penilaian media interaktif kepada 3 orang validator dan 2 orang praktisi, yaitu terdiri dari validator ahli media, validator ahli materi, validator ahli bahasa dan 2 orang guru sebagai validasi praktisi. Media interaktif yang telah dibuat dinilai dan direvisi agar menghasilkan hasil akhir yang sesuai dengan kebutuhan. Revisi produk dilakukan sesuai kritik, saran dan komentar dari masingmasing validator dan praktisi. Setelah media interaktif dinilai dan dilakukn revisi, tahap selanjutnya yaitu tahap uji coba satu-satu dan uji coba terbatas. Pada uji coba satu-satu dilakukan pada tanggal 14 Desember 2021 di Pekanbaru dengan 3 orang siswa kelas III SD. Sedangkan uji coba terbatas dilakukan pada tanggal 15 Desember 2021 di SD Al-Furqon Islamic School Pekanbaru dengan 8 orang siswa kelas III SD.

Tahap keempat yaitu tahapan implementasi. Pada tahapan implementasi ini, seharusnya peneliti melakukan pengaplikasian terhadap media interaktif dengan uji coba publik. Namun, dalam proses pembuatan media interaktif ini peneliti hanya sampai melakukan pada tahap pengembangan saja. Hal ini disebabkan karena beberapa faktor atau kendala kondisi saat ini masih dalam pandemi Covid-19 dan tidak memungkinkan untuk melakukan uji coba publik.

Tahapan yang terakhir yaitu tahap evaluasi. Pada tahapan evaluasi ini dilakukan dengan mengevaluasi tahap penilaian yang dilakukan seperti validasi media interaktif dan uji coba produk. Pada tahap ini peneliti membandingkan hasil uji coba produk dan kelayakan media interaktif. 


\section{Kiprah Pendidikan}

\section{Kelayakan Media}

Kelayakan media interaktif dapat dilihat melalui hasil penilaian validasi dan uji coba. Validasi yang dilakukan oleh 3 orang validator dan 2 orang praktisi, yaitu ahli media, ahli materi, ahli bahasa, dan 2 orang praktisi. Sedangkan pada uji coba, dilakukan dengan 2 tahapan yaitu uji coba satu- satu dan uji coba terbatas. Pada penilaian media interaktif dilakukan dengan menggunakan angket skala 1-4.

Penilaian media interaktif terdiri dari 5 aspek. Pada aspek pertama yaitu aspek materi menunjukkan rata-rata skor 95\% dengan kategori sangat valid. Aspek penilaian kedua yaitu aspek desain media interaktif, pada aspek ini didapatkan rata-rata skor $96 \%$ dengan kategori sangat valid. Aspek ketiga yaitu aspek kesederhanaan, pada aspek ini didapatkan rata-rata skor 95\% dengan kategori sangat valid. Aspek keempat yaitu keterpaduan, pada aspek ini didapatkan rata-rata skor 92,5\% dengan kategori sangat valid. Aspek kelima yaitu keseimbangan, pada aspek ini didapatkan rata-rata skor $100 \%$ dengan kategori sangat valid. Dari kelima aspek tersebut, diperoleh rata-rata skor akhir dari penilaian validasi dan praktisi dengan menunjukkan skor 95,7\% dengan kategori sangat valid.

Media pembelajaran dapat dikatakan layak jika telah memenuhi beberapa kriteria. Kelayakan media dapat diperoleh dari penilaian yang dilakukan oleh ahli materi, ahli media, ahli bahasa, praktisi, uji coba satu- satu, dan uji coba terbatas. Adapun hasil penilaian dari media pembelajaran dapat dilihat sebagai berikut: Validasi Ahli Media mendapatkan skor persentase 94\%, Validasi Ahli Materi mendapatkan skor persentase 100\%, Validasi Ahli Bahasa mendapatkan skor persentase 92\%, Validasi Praktisi I mendapatkan skor persentase 95\%, Validasi Praktisi II mendapatkan skor persentase 96\%, Uji Coba Satu-satu mendapatkan skor persentase 83,33\%, Uji Coba Terbatas mendapatkan skor persentase $89,7 \%$,

\section{SIMPULAN}

Dari hasil penelitian yang dilakukan menunjukkan penilaian terhadap media interaktif terdiri dari 5 aspek. Penilaian media interaktif Genially terdiri dari 5 aspek. Pada aspek pertama yaitu aspek materi menunjukkan rata-rata skor 95\% dengan kategori sangat valid. Aspek penilaian kedua yaitu aspek desain media interaktif, pada aspek ini didapatkan rata-rata skor $96 \%$ dengan kategori sangat valid. Aspek ketiga yaitu aspek kesederhanaan, pada aspek ini didapatkan rata-rata skor 95\% dengan kategori sangat valid. Aspek keempat yaitu keterpaduan, pada aspek ini didapatkan rata-rata skor 92,5\% dengan kategori sangat valid. Aspek kelima yaitu keseimbangan, pada aspek ini didapatkan rata-rata skor $100 \%$ dengan kategori sangat valid. Dari kelima aspek tersebut, diperoleh rata-rata skor akhir dari penilaian validasi dan praktisi dengan menunjukkan skor 95,7\% dengan kategori sangat valid.

Penilaian yang dilakukan oleh validator dan praktisi mendapatkan kategori sangat valid dengan skor : validasi yang dilakukan oleh ahli media mendapatkan skor 94\%, validasi yang dilakukan oleh ahli materi mendapatkan skor $100 \%$, validasi yang dilakukan oleh ahli bahasa mendapatkan skor $92 \%$, validasi yang dilakukan oleh praktisi I mendapatkan skor 95\%, dan validasi yang dilakukan oleh praktisi II mendapatkan skor $96 \%$. Jadi skor rata-rata yang diperoleh dari validasi dan praktisi mendapatkan skor 95,4\%. Hasil dari uji coba satu satu dengan 3 orang siswa didapat skor rata-rata 83,33\% dengan menunjukkan kategori sangat layak. Tahapan selanjutnya yang dilakukan oleh peneliti yaitu uji coba terbatas yang dilakukan pada 8 orang siswa yang terdapat di SD Al-Furqon Islamic School Pekanbaru, skor rata-rata yang didapatkan 89,7\% dengan kategori sangat layak. 


\section{DAFTAR PUSTAKA}

Arif S Sadiman. (2009). Media Pendidikan: Pengertian, Pengembangan dan Pemanfaatnya. Jakarta:Rajawali Press.

Dakir, H. (2004). Perencanaan dan Pengembangan Kurikulum. Yogyakarta: Rineka Cipta.

Ibda, F. (2015). Perkembangan kognitif: teori jean piaget. Intelektualita, 3(1). 1-7

Irwandani, I., \& Juariyah, S. (2016). Pengembangan media pembelajaran berupa komik fisika berbantuan sosial media instagram sebagai alternatif pembelajaran. Jurnal Ilmiah Pendidikan Fisika Al-Biruni, 5(1), 33.

Julianus dan Jesi Alexander Alim. (2018). Pengembangan Media Pembelajaran Matematika Interaktif Berbasis Komputer pada Topik Bilangan Bulat untuk Siswa SD Pendidikan Matematika FKIP UNRI. Jurnal Tunjuk Ajar, 1(1). 1-13.

Muhson, A. (2010). Pengembangan Media Pembelajaran Berbasis Teknologi Informasi. Jurnal Pendidikan Akutansi Indonesia. 8(2), 1-10.

Nazir, Moh. (2014). Metode Penelitian. Bogor: Ghalia Indonesia.

Noveri \& Ety Hayati. (2020). Media Pembelajaran Bahasa dan Sastra Indonesia dan Teknologi Informasi. Tangerang:UNPAM Press.

Nurrita, T. (2018). Pengembangan media pembelajaran untuk meningkatkan hasil belajar siswa. MISYKAT Jurnal Ilmu-Ilmu Al-Quran Hadist Syari Ah Dan Tarbiyah, 3(1), 171-210.

Priandana, V., \& Asto. (2015). Pengembangan Media Pembelajaran Multimedia Interaktif Berbantuan Software Macromedia Flash Pada Kompetensi Dasar Menerapkan Macammacam Gerbang Dasar Rangkaian Logika di SMK Negeri 2 Bojonegoro. Jurnal Pendidikan Teknik Elektro. 4(1), 177-181.

Saidah, Karimatus dan Rian Damariswara. (2019). Pengembangan Bahan Ajar Materi Dongeng Berbasis Kearifan Lokal Jawa Timur bagi Siswa Kelas III SD. Jurnal Pendidikan Dasar dan Pembelajaran Premiere Educandum. 9 (1). Hal 73-81.

Setyawan, A. (2012). Pengembangan Media Pembelajaran Berbasis Adobe Flash Professional Cs6 pada Mata Kuliah Hidrolika di Jurusan Teknil Sipil dan Perencanaan Universitas Negeri Yogyakarta. Jurnal Ekonomi \& Pendidikan. 8 (20), 58.

Sugiyono. (2015). Metode Penelitian Pendidikan pendekatan Kuantitatif, Kualitatif dan R\&D. Alfabeta. Bandung.

Suryono, I. (2011). Belajar dan Pembelajaran Teori dan Konsep Dasar. Bandung: PT Remaja Rosdakarya 